\title{
Polarisation vs consensus-building: How US and German news me- dia portray climate change as a feature of political identities
}

\author{
Robin Tschötschel ${ }^{\mathrm{a}}$
}

amsterdam School of Communication Research, University of Amsterdam, Amsterdam, The Netherlands

\author{
Nieuwe Achtergracht 166 \\ 1018 WV Amsterdam \\ The Netherlands \\ ORCID: 0000-0002-5469-324X \\ E-mail address: r.s.tschoetschel@uva.nl robin.tschoetschel@gmail.com
}

Funding and Disclosure Statement: This research was conducted without the use of external funding and the researcher reports no conflicting interests due to affiliations with public, political, or commercial organisations. 


\title{
Polarisation vs consensus-building: How US and German news me- dia portray climate change as a feature of political identities
}

\begin{abstract}
Perceptions of climate politics often align with individual political leaning and associated media consumption patterns, pointing to a need for a finegrained understanding of how the media integrate climate change with political identities. This study presents an in-depth qualitative analysis of political identity portrayals from 229 articles published in six German and US news outlets during May-July 2019. The results show that the outlets consumed by left- and right-leaning audiences emphasise oppositional identity portrayals, portraying features that are likely to trigger a negative response towards political identities typically opposed by their recipients. The outlets with a more balanced or centrist audience offer a wider array of identity portrayals and emphasise policy questions over fundamental beliefs. Observed patterns differ considerably between Germany and the US, reflecting political and media system differences. The results add to understanding how the media contribute to political polarisation and consensus-building regarding climate change.
\end{abstract}

Keywords: news coverage, identity, polarisation, climate change, comparative research, qualitative analysis

\section{Introduction}

Can you imagine a conservative politician advocating for constitutionally enshrining climate protection as an obligation of government? In most national contexts, this would be a challenging task. But in summer 2019, Markus Söder, the leader of the German Christian Social Union in Bavaria (CSU) and arguably the second-most important conservative politician in the country (next to then-chancellor Angela Merkel), proposed this idea alongside more concrete policy proposals. The press coverage in response offered a glimpse of how conservative identities might incorporate pro-climate ideas.

Most efforts to tackle climate change with the urgency the problem demands require broad societal and political support, and climate politics are arguably one of the drivers of changing political cleavages (Ford \& Jennings, 2020). However, in some countries, including the United States, climate change politics is strongly polarised (Clark et al., 2019) and appears 
to deepen existing divisions. Yet, part of this apparent polarisation is not based on actual attitudes and beliefs but the result of a "perception gap" (Yudkin et al., 2019), exaggerating perceived differences between political partisans over the reality of existing divisions. Such misperceptions matter since many people rely on mental heuristics when engaging with politically complex issues such as climate change (Rugeley \& Gerlach, 2012). Knowledge about the beliefs and attitudes of social and political groups can help navigate the political landscape and the otherwise possibly distant and intangible policy options regarding climate change.

The news media are an important source of information about the politics of climate change and one of the key drivers of public perceptions of the issue (Bolsen \& Shapiro, 2017). Still, media outlets report differently on climate change and politics. For example, the prominence of dismissive or sceptical stances tends to align with politically segmented audience profiles (Feldman et al., 2011; Schmid-Petri, 2015). Consequently, individual media consumption patterns are often in line with political preferences (Newman et al., 2018b). They are one of the key factors in explaining how political attitudes towards climate-friendly policies develop and follow partisan patterns (Feldman et al., 2014; Gustafson et al., 2019; Newman et al., 2018b). Yet, the mechanism linking media consumption patterns to changing attitudes is not fully known, pointing to a need for studies going beyond thematic or frame analysis most common in studies of news reporting on climate change.

Over the past few years, political actors and questions increasingly feature in media reporting on climate change (Tschötschel et al., 2020), reflecting the trend towards a focus on policies rather than climate science denial (Schmid-Petri, 2017). Despite this development, few studies have examined how different news media integrate climate change with existing and new political identities (Morris, 2020). Understanding better what kind of identity portrayals of politically relevant actors are advanced by different media potentially adds a key piece to explaining the relationship between perceptions of political identity and attitudes towards climate policies and media consumption patterns.

Across countries and media organisations, journalists and editors must navigate different political and media institutions, cultural norms, and organisational requirements (Reese \& Shoemaker, 2016). Additionally, economic and environmental histories in different countries have created various path dependencies and policy options for climate politics - meaning that contextualisation and cross-national comparison are crucial for empirically driven theory-formation. The countries in focus in this study, Germany and the United States, are major per-capita emitters and have considerable investments in their automobile manufacturing and fossil fuel-dependent energy production industries. Yet, the political response to climate 
change in each country and reporting on the issue differ considerably (Tschötschel et al., 2020), as do political and media systems (Brüggemann et al., 2014; Hallin \& Mancini, 2004). Thus, the comparative approach presented here facilitates dissecting media portrayals of climate-related aspects of political identities and enables a context-sensitive explanation of how they fit into the bigger picture of national climate politics. The following question captures the research aim of this study.

(1) How do news media in Germany and the US integrate climate change in their portrayals of politically relevant identities?

\section{Social Identity and Politics}

Identity is a complex, multi-faceted phenomenon studied using a variety of social scientific approaches. Foregoing an in-depth discussion of how different traditions conceptualise identity, in this study, I build on social-psychological "social identity theory" (Hogg \& Reid, 2006) and "self-categorisation theory" (Turner et al., 1994). Following this literature, individuals are familiar with a range of "social identity prototypes" (Hogg \& Reid, 2006) - shared mental representations of different identities corresponding to social groups individuals can identify with or consider as 'Others'. The relationship between the individual self and social identities is complex, as people can change their perceptions and evaluations of the identity prototypes they know and adjust the strength of identification with (or rejection of) different prototypes and the groups they represent (Ellemers et al., 2002). Yet, according to social identity theory, people generally "search for positive distinctiveness" (Brown, 2020) in comparison to others, potentially explaining a range of phenomena commonly associated with identity politics.

Individuals can know a vast repertoire of social identity prototypes, ranging from relatively a-political (e.g. 'avantgarde musician') to clearly political (e.g. 'Republican', 'Green party member'). However, there is no clear-cut a-priori distinction between political and apolitical identities since social identity prototypes are multi-dimensional collections of identity markers that can be associated with individuals and groups. These are "fuzzy sets, not checklists, of attributes" (Hogg \& Reid, 2006, p10), including values, attitudes, norms, goals, behaviours, etc. Consequently, 'political' characteristics can be part of 'non-political' identities and vice-versa. However, when identity markers become a part of a political identity — one strongly associated with the political realm - they can be explicitly politicised and can open a new line of political conflict, for example between allegedly radical "Millennials" and moderate political forces (Morris, 2020). 
Political identities take a central role in understanding contemporary political phenomena, not limited to identity politics: They provide heuristics for navigating the political landscape and offer individuals a way of engaging with politics, not requiring an in-depth understanding of policy or institutions. Particularly noteworthy are identities associated with political parties competing in elections — partisan identities (Huddy, 2015). Partisan identity cues can trigger recipients into "motivated reasoning" that helps interpret information congruent with one's existing cultural and political worldviews (Hart \& Nisbet, 2012).

\section{Climate Change and Partisan Political Identity}

When an issue, such as climate change, takes an increasing share of the political stage, it can form the basis of new political identities and transform existing ones. Cast in these terms, the success of political advocates and activists depends on their ability to a) build an identity that is powerful enough to influence politics independently or b) to alter existing identities in a way such that their desired positions have powerful backing. If and how these dynamics play out at the level of political parties (and thus partisan identities) depends to a considerable degree on political institutions. When the political system allows new parties to be formed and enter representative politics easily, this is likely to happen - as can be seen in many European countries where 'Green' parties have entered national parliaments (Grant \& Tilley, 2018). In other cases, such as the US, where the system discourages the formation of new parties, advocates must influence existing parties to get their issue and positions on the political agenda.

Narrowing in on the politics of climate change, the extant literature has discussed how the seemingly non-partisan 'ecological' or 'environmental' identity (Light, 2000; Werff et al., 2013) can include an attitude that favours climate-friendly behaviour and policies. However, these labels are relatively marginalised in public political discourse, at least when compared to established identities (e.g. "Left", "Right", "Conservative", "Liberal", or partisan identities). Yet, in Europe, following the successes of the Green parties often perceived to be frontrunners of climate-friendly policies, many mainstream parties have followed suit by adopting a stance on the issue (Farstad, 2017). This does not necessarily mean that all of them advocate for progressive political responses, but few parties outright ignore the issue. In the US, positions on climate change have become an element of party politics as well. Arguably, the Democratic party considers dealing with climate change part of their identity, but how so is subject 
to internal debate. The Republican party's position on the issue can be summarised as: 'government should not be dealing with climate change if it even exists' (Republican Party, 2016), making it an anomaly among conservative parties (Båtstrand, 2015).

\section{Studying Mediated Identity Portrayals}

Media play an important role as "gatekeepers" in selecting who and what makes the news (Vos \& Shoemaker, 2009). Furthermore, they emphasise specific aspects and characteristics of the issues and actors reported on by using frames to reduce the complexity of real-world events in their reporting (Chong \& Druckman, 2007). Notably, the ability to select actors and frame issues highlights that portrayals of political actors differ to a degree depending on the media consumed. An indication of the power of the media and political communication can be gleaned from media effects studies that highlight how media consumption patterns relate to public perceptions of climate change and political positions on the issue (Feldman et al., 2014; Gustafson et al., 2019).

How media and public discourses could shape perceptions of identity has been studied frequently using discourse analytical approaches by focusing on the "speaker positions" and "subject positions" constructed in public discourse (Benwell \& Stokoe, 2006). In the field of climate change communication, some studies have built on this approach, or one of its variants (Boykoff, 2008; Pepermans \& Maeseele, 2018; Weingart et al., 2000). However, despite many calls to focus on the subjectivities and identities portrayed, few studies, discourse-analytical and otherwise, have rigorously empirically investigated such portrayals in news coverage of climate change (Carvalho et al., 2017). Overall, the extant literature on media and identities thus points to the need for a) an analysis that distinguishes between different media and b) an approach sensitive to fine-grained differences between individual portrayals, allowing the analyst to disentangle who exactly says what about whom.

\section{Associational Identity Analysis}

To do justice to the complex, controversial, and fluid nature of identities, I develop a theoretical and methodological approach I call "associational identity analysis", inspired by ActorNetwork Theory (ANT). Put briefly, ANT as social theory conceptualises the nature of social reality as an outcome of ongoing practices that make (and break) "associations" between different actors resulting in groups and categories (Latour, 2005). These associations include shared practices, membership in organisations, belief in the same ideas, contractual ties, etc. 
ANT empirically centres how the actors studied create and contest associations amongst each other, typically using ethnographic methods (Michael, 2017; Venturini, 2009). However, how the media portray associations and group memberships has received relatively little attention in the ANT-inspired literature. In contrast, in this study, departing from its typical application and methods, I use ANT as an analytical lens to study associations expressed in news reporting and use these to reconstruct the identity portrayals depicted in the media.

Theoretically speaking, associational identity analysis highlights that media portrayals do multiple things simultaneously. First, by writing about social groups and their behaviours, norms and opinions, media associate the latter with the social identity prototype of that group directly, often normatively evaluating the identity along the way. Second, media portray individuals as representing certain groups, giving them a platform to influence perceptions of the social identity prototype associated with the group they arguably speak for (if the audience accepts this function as a "spokesperson" (Latour, 2005)). Third, when individuals talk about other groups they are not typically identified with (e.g. a conservative politician speaking about left-wing voters), they potentially influence audience perceptions of that outside group. But more importantly, this portrayal also makes this other-perception a part of the identity prototype associated with the speaker. Using an approach that analytically distinguishes these different aspects thus enables detailed reconstruction of how media and the people they use as sources portray political identities.

\section{Methods and Material}

Building on the theoretical considerations discussed above, this section presents a methodological operationalisation of associational identity analysis. The merits of this procedure lie in a primary coding stage that can serve as the basis for both qualitative and quantitative analyses, a theory-agnostic empirical engagement with the material, and a high degree of adaptability to emerging research questions and concerns, thus enabling open inquiry and theoryformation.

\section{Outlet selection and sampling}

The material analysed here stems from the output of six news outlets selected to represent three different types of news sources per country: one consumed mainly by those identifying with the political right, one consumed by those leaning to the left, and one read by both groups alike. Following the past years' trend towards online news consumption, I focus 
Figure 1: Online media audience profiles in Germany and the United States

\section{a) Germany}

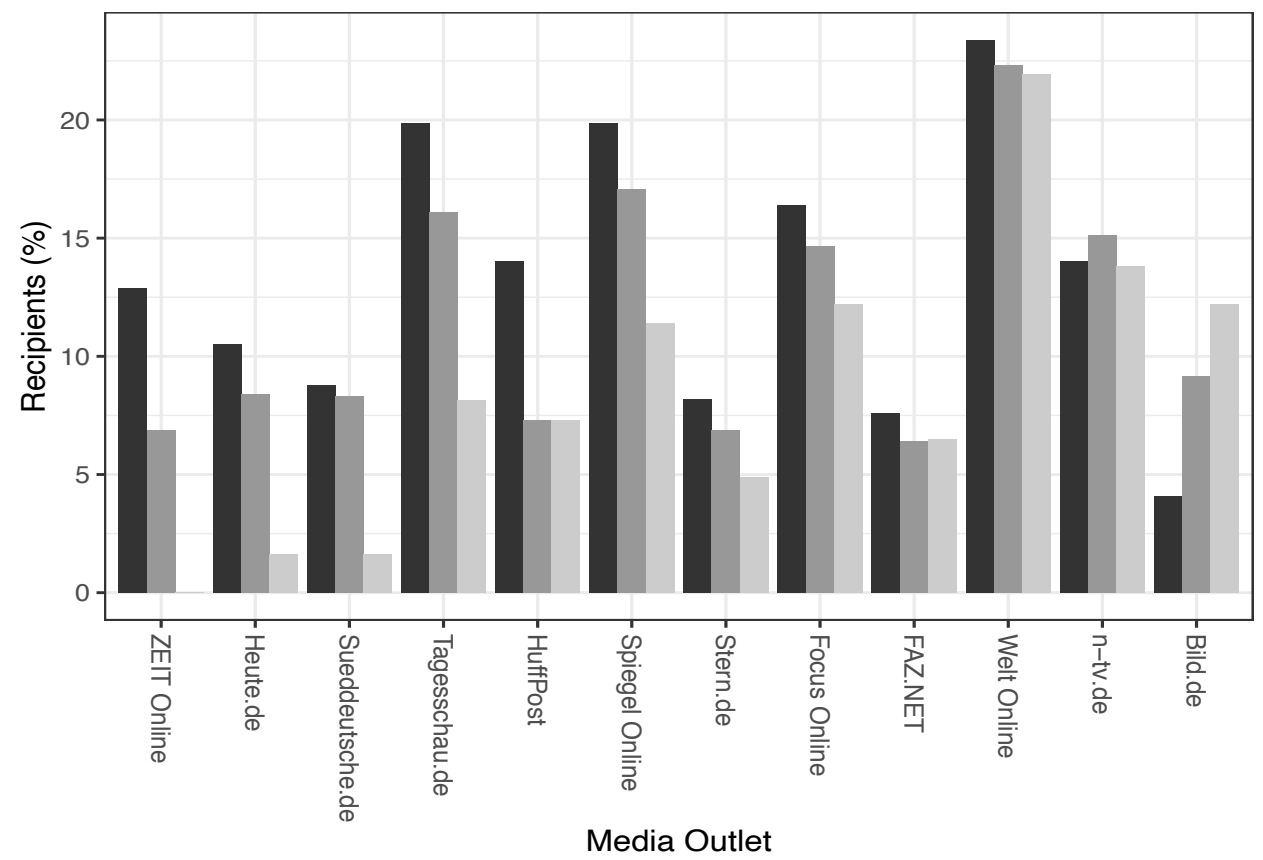

Audience Group

Left

Centre

Right

b) United States

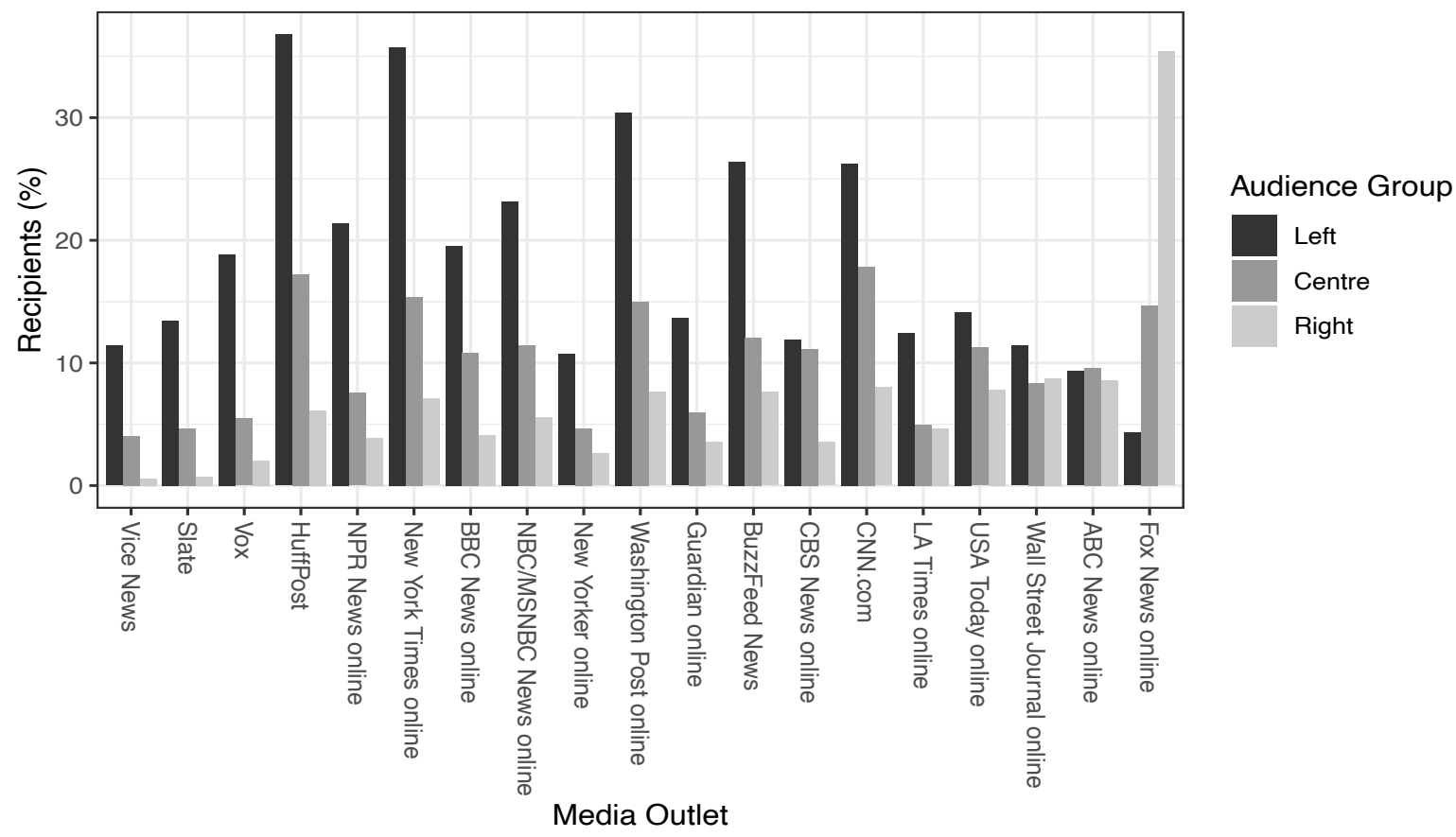

Audience groups are respondents identifying as "Very left-wing" or "Fairly left-wing", "Slightly left/right of centre" or "Centre", "Very right-wing" or "Fairly right-wing". Recipients (\%) are percentages of respondents within each audience group stating they consumed the respective outlet last week. Media outlets are all outlets with an overall audience share $>5 \%$ and exclude news aggregators (Google News, Yahoo, etc.). They are ordered by the ratio of left-wing audience share divided by right-wing audience share. 
on online news sites, independent of their background as print, television, or digital-born news media. Using data from the Reuters Digital News Report (Newman et al., 2018a) on self-declared political orientation and news consumption behaviour, I selected foxnews.com, abcnews.go.com, and huffpost.com in the US, and bild.de, welt.de, and sueddeutsche.de in Germany. Figure 1 illustrates each outlets position in the online media landscape, and Table 1 offers more details about their audience profiles.

These websites' output (both articles and videos) was monitored using their official RSS feeds, and each item published checked for climate-change-related content using a simple filter. Validation of this filter using a random selection of news items by one hired research assistant and the author showed good results: Using a set of manually coded articles (Intercoder Agreement: Krippendorf's alpha .89) to check its quality, the filter identified $85 \%$ of relevant news items.

Table 1: Audience percentages and news items analysed per outlet

\begin{tabular}{|c|c|c|c|c|c|c|}
\hline \multirow[b]{2}{*}{ Outlet } & \multicolumn{3}{|c|}{ Audience $^{\mathrm{a}}(\%)$} & \multicolumn{3}{|c|}{ News Items } \\
\hline & Left & Centre & Right & Published $^{\mathrm{b}}$ & Flagged $^{\mathrm{c}}(\%)$ & Analysed $^{\mathrm{d}}(\%)$ \\
\hline Bild & 4 & 9 & 12 & 13002 & $134(1.0)$ & $51(38.1)$ \\
\hline Die Welt (N24) & 24 & 22 & 22 & 12734 & $466(3.7)$ & $55(11.8)$ \\
\hline $\begin{array}{r}\text { Süddeutsche } \\
\text { Zeitung }\end{array}$ & 9 & 8 & 2 & 9241 & $243(2.6)$ & $35(14.4)$ \\
\hline Fox News & 4 & 15 & 35 & 18289 & $102(0.6)$ & $27(26.5)$ \\
\hline ABC News & 9 & 10 & 9 & 2786 & $24(0.9)$ & $21(87.5)$ \\
\hline Huffington Post & 37 & 17 & 6 & 5747 & $74(1.3)$ & $37(50.0)$ \\
\hline Total & & & & 61799 & 1043 & 229 \\
\hline
\end{tabular}

a Shares of respondents identifying as "Very" or "Fairly left-wing", "Slightly left/right of centre" or

"Centre", "Very" or "Fairly right-wing" who say they have consumed the online outlet in the past week.

b Number of news items appearing in the official RSS feed between May 1 and July 31, 2019.

c Items flagged to contain information about climate change (percentage of all published items).

d Items subsequently selected for in-depth analysis (percentage of flagged items)

Aiming to stratify our data across the investigation period, I randomly sampled a maximum of 4 items per outlet per week between May 1 and July 31, 2019. This procedure was chosen over other sampling strategies to avoid cherry-picking items that might be in line with 
unreflected expectations and to facilitate formulating hypotheses and theoretical accounts that warrant further quantified theory-testing. In some weeks, outlets published less than four relevant items, resulting in slightly different amounts analysed per outlet - Table 1 provides an overview of these data characteristics. Ultimately, out of 1043 items flagged to involve climate change in this period, my research assistant and I analysed 229 in-depth. Supplementary material (S1) provides a collection of all articles analysed and referenced in this article.

\section{Primary Coding}

To analyse the corpus of news articles in-depth, my research assistant and I used a two-stage coding approach. First, we coded all associations systematically line-by-line. Each code consists of four elements: the two "entities" (individuals, groups, organisations) that are linked (individual markers, or groupings), the relationship between them, and the entity expressing the association (figure 2).

Figure 2: Coding scheme and examples for associational identity analysis

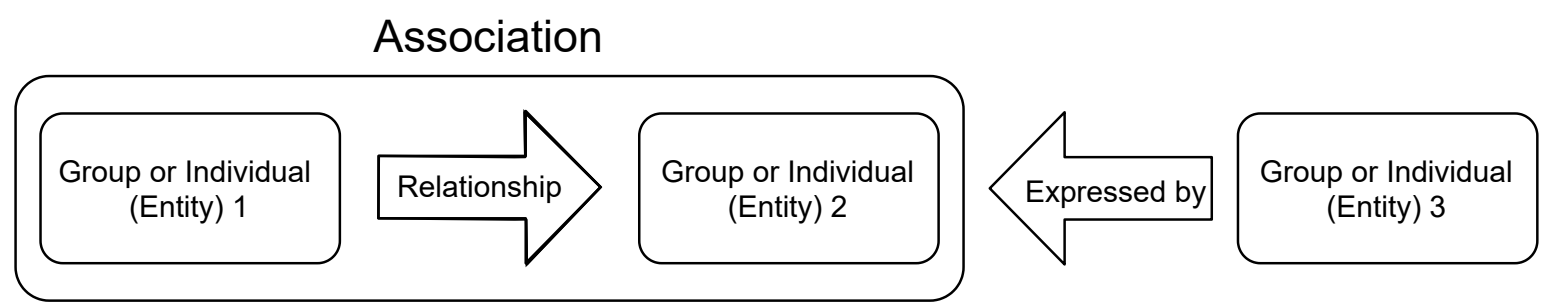

Climate activist Greta Thunberg, ...

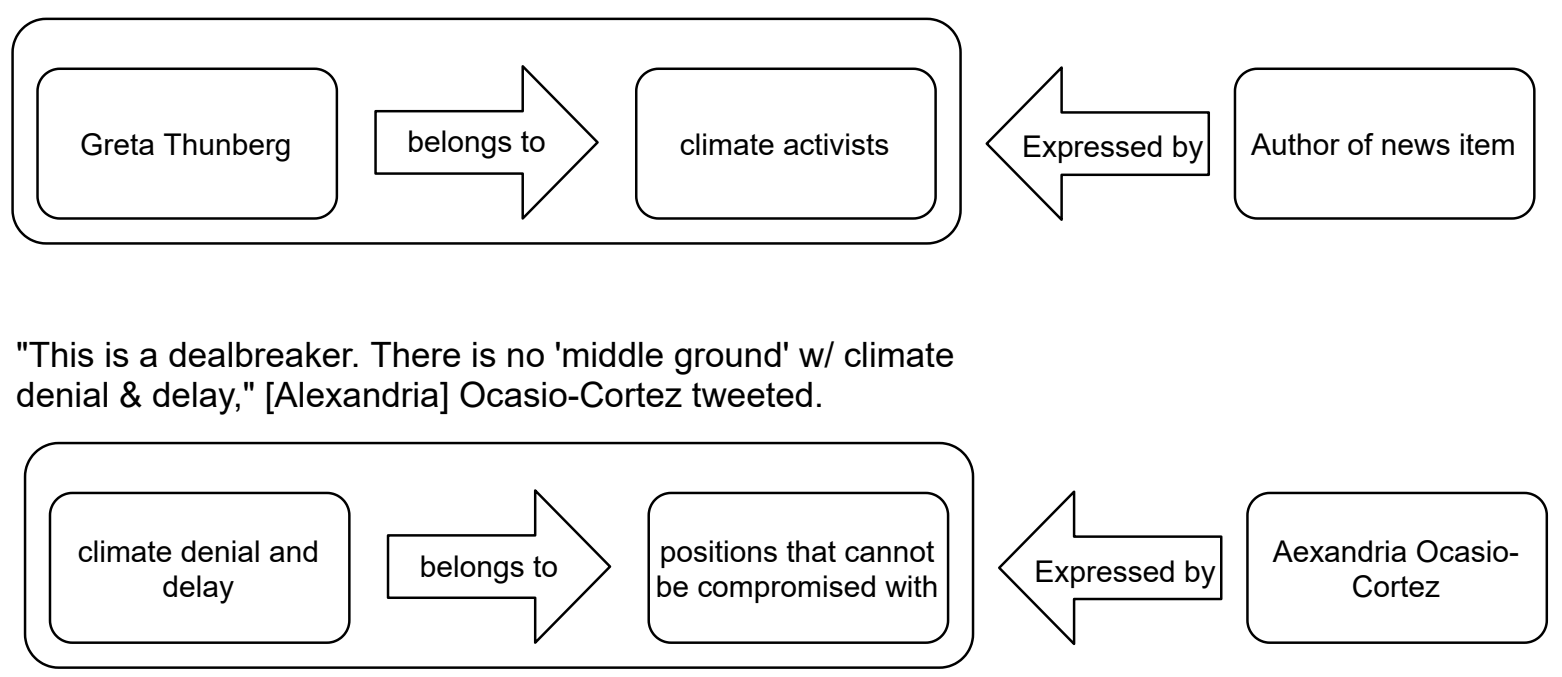


Associations vary from simple to complex. For example, applying an identity label to a person, such as "climate activist Greta Thunberg," simply categorises Thunberg as a climate activist (associating her with that group). On the other end, consider the statement "those demanding a price on carbon emissions ignore the risks such an intervention poses for jobs and economic growth." This phrase constructs two groups, "people demanding a price on carbon emissions" and "people who care about jobs and economic growth," claiming that the first does not belong to the second. It also constructs another association, a factual claim that a "price on carbon emissions" belongs to the group of "things that pose a risk for jobs and economic growth."

The last part of the code, the expressing "entity", allows the analyst to distinguish between in-group self-portrayals and those stemming from an actor belonging to other groups (for example, the journalist writing the article or a political opponent). This distinction facilitates a detailed reconstruction of how different groups and individuals define and portray themselves, their political opponents, and others.

We coded all statements that made relevant associations, given our research interests - meaning we ignored all associations that were not in some way related to climate change or climate-related policy or politics. Note that coding these often-complex statements always includes interpretation and abstraction. Still, the empirical approach developed here allowed us to analyse associations at all levels of complexity with empirical rigour.

\section{Secondary Analysis}

In the second stage of analysis, I revisited the primary codes and analysed the coded material. First, I identified identities central to this analysis. This was chiefly driven by the a-priori focus on partisan political identities (those associated with political parties). However, one other group of actors appeared as a central political subject in the material: the young protesters that went on school strikes and took to the streets achieved a considerable media presence, particularly in Germany, and are thus included in this analysis. While a prominent actor group in climate change news, scientists were only infrequently portrayed with a political stance and are therefore excluded from this presentation. An in-depth analysis of the separation between politics and science in news reporting would make an interesting subject of study but is beyond the scope of this article.

Second, adopting an approach akin to a logic of theoretical sampling (Glaser \& Holton, 2004), I identified which types of associations drive identity portrayals, resulting in three 
categories. First, associations based on behaviours denote the things people do, be it deliberate or inadvertently. Second, those based on objects of knowledge represent ideas concerning social and physical reality. They include both prescriptive values and norms - rules for behaviour aimed at promoting or protecting something that is considered valuable - and descriptive claims such as facts, cause-and-effect relationships, explanations, etc. Finally, I separated policy positions (the attitudes to and beliefs about policy ideas and specific policies) from other objects of knowledge, reflecting the fact that much political discourse revolves around policy. The results of this systematisation are presented for each outlet and identity group in appendix A2 and are exemplified in table 2.

Table 2: the "Green New Dealers" in Fox News

\begin{tabular}{|c|c|c|}
\hline Behaviours & Objects of Knowledge & Policy Positions \\
\hline $\begin{array}{l}\text { lie to their own support- } \\
\text { ers }^{1} \text {; use apocalyptic lan- } \\
\text { guage }^{6} \text {; want to end the } \\
\text { debate on climate } \\
\text { change }^{6} \text {; link tornado } \\
{\text { warnings to } \mathrm{CC}^{10} \text {; dis- }}_{\text {credit their opponents }}{ }^{17} \text {; } \\
\text { would send the econ- } \\
\text { omy into depression }^{17}\end{array}$ & 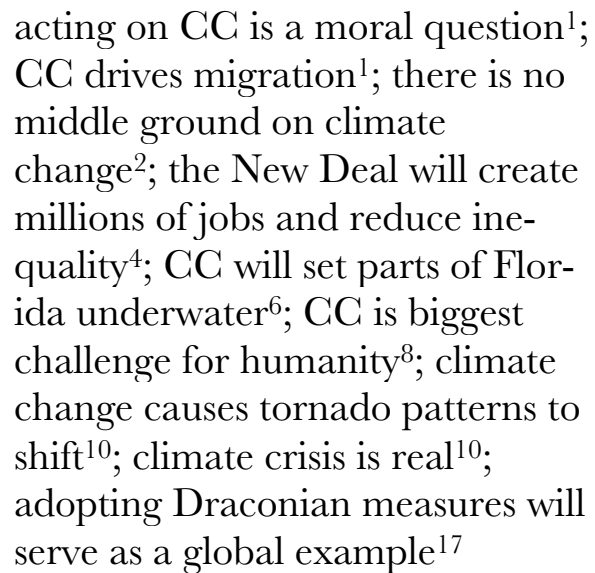 & $\begin{array}{l}\text { support the Green New } \\
\text { Deal }{ }^{1,10} \text {; a radical reor- } \\
\text { ganisation of the entire } \\
\text { economy }{ }^{1,4} \text {; provide } \\
\text { prosperity and economic } \\
\text { security to all Ameri- } \\
\text { cans }^{4} ; 100 \% \text { renewables } \\
\text { a } 100 \% \text { job guarantee; } \\
\text { government-focused pol- } \\
\text { icies }{ }^{6} \text {; take money from } \\
\text { rich people } \\
\text { expansion }{ }^{17} \text { massive tax }\end{array}$ \\
\hline
\end{tabular}

Note: References to news items can be found in Appendix A1

Third, I developed a theoretical interpretation of how each outlet portrays the three identities, using techniques derived from abductive analysis (Tavory \& Timmermans, 2014): defamiliarisation from "normal" modes of news consumption, revisiting my data on multiple occasions over time, and developing alternative accounts, weighing their explanatory power against each other. The following section presents the outcome of this first step of theory-formation, serving as a basis for an integrative discussion following thereafter.

\section{Empirical Results}

As I take up each outlet in turn, I discuss the identity constructions gleaned from my data as if they were factual. These interpretations are rooted in statements made by the authors of the news item or by giving voice to somebody carrying the identity label. Statements about other groups are seen as ways of defining one's own identity and are included in these descriptions 
as other-perceptions (see Methods discussion above) — rather than taken as objective statements describing the other group. References to news items are numbered by outlet (see Appendix A1).

\section{The United States}

In the United States, the build-up to the Democratic Party's primary election received ample attention from the news media and drove reporting about climate politics and policy. Media portrayals focused on proposals for a "Green New Deal," a package of economic and environmental (climate) policy reforms. On the other side of the aisle, coverage focused on Republicans' opposition to the Green New Deal, resistance to climate legislation, and the Trump administration's rollback of environmental regulations. Portrayals of young activists (most frequent in Huffington Post) complemented the picture.

\section{Fox News: Beware the socialists}

Fox News centres its climate-related reporting on mainstream US Democrats and the "Green New Dealers". Dominating the Democratic party, the latter see climate change as a moral issue that warrants a "radical"l transformation of the country's economy, where "middle ground" approaches are not enough ${ }^{2}$. In most of Fox News' coverage, the Green New Dealers also want to expand the welfare state through 'job guarantees,' combating economic injustice, and increasing government intervention in the economy ${ }^{1,4}$. They are ready to "weaponise the government" 3 — using executive power ${ }^{5}$ and prosecuting climate change skeptics ${ }^{3,5}$. Since coverage of 'moderate' Democratic positions or conflict within the party is rare, Fox News paints a strongly prototypical picture of Democratic identity as essentially socialist, using climate change as a pretence.

Scared by Democratic "apocalyptic language"4 and their attempts to wrongfully link climate change to migration and specific extreme weather events, young voters (millennials) "see the threat of climate change as real," want action on climate change, and ignore "rational debates on the topic" ${ }^{11}$. Some of them, organised in the Sunrise Movement comprised of democratic millennials, actively lobby for the Green New Deal².

Republicans, on the other hand, are ready to defend their constituent's interests using their constitutional rights, such as "walking out" the Oregon legislature to prevent a vote on a climate bills. And overall, "Republicans, including in the White House, have been sceptical about climate change and have opposed Democrats' government-focused ideas to combat the 
threat" . Consequently, they are equivocally critical of the Green New Deal, with some viewing it as a "radical, top-down, socialist makeover of the entire US economy"4, in line with the portrayals of Democrats by Fox News.

In sum, Fox News follows the version of identity politics promoted by Republicans appearing in the outlet, painting the political conflict around climate change as a matter of defending America against a radical-left, socialist attempt to use whipped-up fears for an expansion of government.

\section{ABC News: Policy focus and intra-party divisions}

In ABC News, most Democrats see climate change as a global, existential threat $2,4,10,18$ that warrants immediate action ${ }^{1,13}$. Most Democratic primary candidates propose policies to tackle the issue by re-joining the Paris Agreement, investing in infrastructure and emissions standards to reduce fossil fuel consumption and GHG emissions $s^{2,4,10,13}$. However, in contrast to Fox, health care and job creation plays a minor role in the coverage of ABC News, and the outlet portrays a broader array of Democratic stances on the issue. Some candidates offer farther-reaching proposals, opposing other 'middle ground' approaches ${ }^{2,4,10,13}$, leading to significant debate within the party ${ }^{13}$.

ABC News highlights the attitudes of young people by citing a Harvard Poll reporting "a substantial 14-point increase [...] in those who said they believed 'government should do more to curb climate change, even at the expense of economic growth" ${ }^{10}$. They also mobilise political scientist Dana Fisher, stating that "active and progressive young Americans [are] probably the most engaged electorate right now"4, placing them in the Democratic camp. Thus, young people appear chiefly as left-leaning voters, albeit this time driven by political considerations and agency, rather than irrational fears.

On the Republican side, ABC News lays the focus on the actions and positions of the Trump Administration. The latter views its policies as environmentally friendly ${ }^{5}$, despite opposing the Paris Climate Accord and the Green New Deal, and rolling back Obama-era regulations ${ }^{3,6}$, which are "destroying jobs" and "singling out" coal". ABC News offers examples of within-party divisions over policy, citing former Republican EPA directors who are seriously 'concerned' over the agency's direction and criticise President Trump's handling of the environment and attitude towards science ${ }^{3}$. 
Overall, ABC News offers much less prototypical portrayals of Republican and Democratic identities, creating an opportunity for the reader to potentially broaden their perception of what it means to be part of either political camp.

\section{Huffington Post: Democratic primary infighting and Republican denialism}

Huffington Post's reporting on Democratic positions focuses firmly on the Green New Deal, here a combination of a commitment to achieving net-zero emissions with job promotion and other welfare and economic reforms ${ }^{2,3}$. However, the different policy proposals separate progressive from centrist factions of the party ${ }^{1}$. The former view climate change as an emergency that has only benefitted fossil fuel companies ${ }^{28}$ - an existential crisis ${ }^{18,19,26}$ that warrants rapid reform ${ }^{3}$ and rejecting middle ground ideas ${ }^{17,19,28}$. In this, they are followed (and sometimes driven) by the liberal and young Sunrise Movement, thinking its "generation's survival is at stake" and demanding more debates focused on the issue ${ }^{3}$.

Accordingly, some members of the Democratic National Committee think that climate change is "the No. 1 issue for younger voters in our party"3. Yet, while there is considerable pressure from the young activist base $\mathrm{e}^{6,7,8}$, the party establishment is apprehensive of placing too much focus on the issue 5 . Similarly, "mainstream" Democrats, while agreeing with the urgency of climate change, advocate for separating climate protection from other reform initiatives or promote more moderate plans ${ }^{4,17}$.

Strikingly, reporting on the Democratic primary is largely disconnected from portrayals of Republicans and the Trump administration, who nonetheless appear frequently. According to Huffington Post, Donald Trump is a climate denier $9,10,11$, opposing meaningful regulation to tackle climate change ${ }^{9}$ and claiming that such policies would "punish" workers and industry, especially in the coal sector. Republicans are generally supporting Trump's views $^{12}$, the Administration's continued deregulation of fossil fuel and car industries ${ }^{13,14}$, and oppose regulation aiming to reduce carbon emissions ${ }^{15}$.

Taken together, the portrayals of Huffington Post present a wide array of Democratic identities in their extensive coverage of the party's primary and are the only outlet giving a relatively prominent position to young activists. On the other hand, Republican's identity portrayals are prototypical, focused on their link to the fossil fuel sector and policy blockade. 


\section{Germany}

In Germany, reporting focused on three issues. First, on a wave of protests by young people, often associated with the "Fridays for Future" movement. Second, on the European parliamentary election and the EU-level policy positions advocated for by different parties. Third, on the so-called "climate cabinet" ("Klimakabinett"), a government task force to develop a policy plan across ministerial competencies to achieve Germany's Paris Agreement commitments. For reasons of parsimony, the discussion presented here excludes "Die Linke" and the "Alternative für Deutschland," receiving almost zero coverage in the media analysed.

\section{Bild Zeitung: Prohibitions vs incentives?}

Bild appears to organise political divisions chiefly around a critique of the Green party as a "Verbotspartei" (prohibition party). Some party members are portrayed as advocating for the prohibition of meat products and plastics ${ }^{11}$. Together with the Social Democrats (SPD), they are frequently shown in their opposition to short-distance flights ${ }^{2,3}$, toying with the idea of prohibiting them all-together ${ }^{2,5,27}$ and promoting train travel instead ${ }^{1,8}$.

However, this emphasis only creates weak opposition to the Union block, supporting a tax reduction on rail tickets to promote a more rapid transition from air to train travel ${ }^{1,2,6,8}$ "without prohibitions." The conflict is more pronounced in portrayals of the market-liberal FDP, attacking the Greens for stoking fear, "moralising" the debate and advocating for a "planned economy"7 that takes away people's cars and meat ${ }^{11}$, arguing this will make people angry and lead to a loss of competitiveness ${ }^{7}$. Considering the FDP-Greens conflict alone, the climate-related portrayals of political identities in Bild Zeitung appear relatively similar exaggerated as Fox News' reporting.

Yet, returning to the governing parties, the picture gets more complicated. The SPD is a staunch promoter of its carbon tax-and-dividend proposals ${ }^{1,19}$, arguing for this approach to reconcile social and ecological issues. Both parties in the conservative "Union" (CDU and C.SU) support German and European climate neutrality by $2050^{6,26}$. The C.SU is creating a more activist profile, for example by arguing climate protection should be part of the "Grundgesetz" (Germany's constitutional-rank "basic law”) ${ }^{8}$, and by supporting a rapid exit from coal ${ }^{6,8}$, which CDU politicians say would affect certain regions out of proportion ${ }^{6,9}$. Thus, both SPD and Union are portrayed to combine climate protection with a concern for social or regional fairness, in line with their prior political identities. 
In Bild, Fridays for Future activists and the German youth receive ample coverage, but this is mostly separate from reporting on parties and policies. According to the outlet, they are driven by a concern over governments' (and grown-ups') ignorance of climate change $^{9,12}$, which they see as an existential threat ${ }^{22,23}$. They skip school to protest peacefully ${ }^{10,23,29}$ (in Germany and Brussels ${ }^{20}$ ) and are successful in making climate change a top issue in the European election ${ }^{21}$. While some activists' opposition to meat consumption and flying brings them close to the Green party, overall, their 'activist' identity is relatively independent of political affiliation.

\section{Die Welt: Consensus for transformation, but how?}

According to Die Welt, almost all political identities include a combined concern for social fairness and commitment to climate protection. The SPD and the Greens want to compensate for the burden of a carbon tax by paying a "climate dividend" to lower-income groups ${ }^{1,2,3,4}$, which they argue will avoid unrest over new taxes (as seen in France) ${ }^{4}$. The Union parties (CDU and CSU) equally express wariness over new burdens on citizens or the economy ${ }^{4}$ out of concern over urban-rural and East-West divides ${ }^{3,7,8}$ as well as social upheaval ${ }^{3,4}$. In "Die Welt", young protesters demand "structural change that also maintains employment"18, established through "concrete measures" rather than mere "commitments"17, allowing governments to live up to their own (Paris Agreement) commitments ${ }^{9}$.

However, policy conclusions differ between parties. In opposition to the carbon taxes favoured by SPD and Greens, the Union prefers emissions trading. Similarly, the FDP, infrequently portrayed in Die Welt, argues against taxes and for a European (if not global) emissions trading scheme to protect economic growth and promote emissions reductions elsewhere ${ }^{4,24}$.

The when and how of the exit from coal-powered energy production is the most substantial dividing issue in Germany, yet it does not follow classical left-right divisions. The government (SPD, CSU, CDU) propose a coal phase-out by 203820,31. For this, they are heavily criticised by Fridays for Future activists, wanting a more rapid exit from coal ${ }^{20}$ and a declaration of climate emergency ${ }^{9}$. Claiming to represent the voices of the Fridays for Future movement $^{7}$, for the Greens, the whole government (consisting of CDU, CSU, and SPD) has slowed down the energy transition and shown a general lack of action on climate change ${ }^{6}$, for example by its slow exit from $\mathrm{coal}^{20}$. 
Overall, Die Welt, similar to ABC News above, offers a broad range of identity portrayals for most parties and emphasises how they combine the desire to act on climate change with their existing party profiles, with proposals and dividing lines changing the political map.

\section{Süddeutsche Zeitung: Youth-determined Zeitgeist vs status quo}

More so than the other outlets, reporting in the "Süddeutsche Zeitung" focuses on young protesters and the Fridays for Future Movement. They are disillusioned with the inaction of politicians in power, allowing corporations to profit from endangering the future of the now young ${ }^{12,13,14,15}$. For some protesters, climate change triggers a question of system change, questioning the legitimacy of capitalism ${ }^{15}$. Being politically active by protesting and striking $^{12,18,20}$, they see grown-ups relying on the movement to set the issue on the agenda and demand their participation in pressuring politics to finally act ${ }^{12}$. Consequently, the young protesters have a relatively strong left-wing identity, and according to the outlet, they flock to the Green party, which benefits from the "Zeitgeist"5 by having a credible stance on the issue.

The Social Democrats claim scientific evidence, presenting multiple studies for their carbon tax and dividend to "reward" climate-friendly behaviour ${ }^{1,8,9}$. Yet, they stress the need to protect commuters and renters ${ }^{2}$ and advocate for expanding the European carbon emission trading scheme ${ }^{2}$, having little new to offer. Similarly vague, the CDU advocates for a long-term (2050) goal of carbon neutrality ${ }^{3,11}$, stressing the need for coordinated action ${ }^{11}$ and global $^{2}$ and national carbon prices ${ }^{9}$. Similarly, the CSU makes its opposition to carbon taxes a central issue ${ }^{6}$ and favours European emissions trading. ${ }^{6}$. While claiming to let "economy, ecology and social affairs go hand in hand," the CSU advocates a climate-neutral Bavaria in $2040^{6,7}$. The FDP, marginally covered in SZ, advocates for the market- and technology-based solutions, with minimal (national or European) state intervention ${ }^{2}$, and claims that changes to the German's current lifestyle shouldn't be necessary4.

Thus, in Süddeutsche Zeitung, the politics of identity related to climate change play out in more abstract terms, centred on the question of who can offer the most inspiring ideas. According to the outlet, absent in-depth discussion of their policies, the Greens appear to do so, while other parties lack vision and present only well-known positions. 


\section{Discussion}

This study set out to study differences and similarities between how German and US media outlets integrate climate change with existing and new political identities. The results presented above reveal remarkable differences between outlets that follow patterns with a certain degree of stability across countries. Therefore, depending on the outlet consumed, audiences will encounter different representations of what it means to be a Democrat or Republican, a member of one of the German parties, or a young citizen.

\section{Political Identities and Climate Change}

This study was chiefly motivated by the question of how media reporting contributes to making climate change a feature of existing political identities or newly emergent ones. Theoretically, I approached identities not as an essential characteristic of groups or individuals, but as media portrayals of 'identity prototypes' (Hogg \& Reid, 2006) that might exercise power by influencing individual perceptions of what it means to be 'Conservative', 'Green', a 'young activist', etc. Taking a step back from the outlet-specific portrayals, I argue that the identitytransforming nature of climate change is apparent in media reporting in both countries and across outlets.

Both the Democrats in the US and the Green party in Germany are across outlets portrayed as having fully embraced climate-friendly policies. The mediatised identity of the German Green party arguably includes elements of the so-called "ecological" or "green identities" associated with environmental movements (Light, 2000). On the other hand, portrayals of US Democrats are focused on how they view climate change as an economic and justice issue, side-lining nature-oriented aspects.

Furthermore, climate change has become an element of the portrayed identities of other German parties as well. Similar to the US Democrats, the German Social Democrats are portrayed to be prominently touting the horn of combining environmental friendliness with social fairness. On the centre-right, the Union parties (CDU and CSU) have managed to be portrayed as the managers of a business-friendly transition to carbon neutrality. And the FDP, with the least pronounced profile on climate change, is presented as the party promising carbon-price driven market solutions and individual freedom from government regulation. Note that all German parties discussed here are portrayed to embrace the idea of economic transformation towards net-zero emissions, thus incorporating elements of an ecological identity. 
The US Republican party is the most complex case, but I would argue that climate change plays a vital role for the party: opposition to climate-friendly policies has become a core element of Republican identity. This view is in line with findings that climate "scepticism" has shifted from science denialism to policy opposition (Schmid-Petri, 2017) — albeit Huffington Post is still emphasising science denial as central to Republican identity.

Next to transforming existing partisan identities, climate change has also driven the emergence of a new (non-partisan) one on the European scene: the Fridays for Future movement. It is organised around a clear yet somewhat abstract demand: more and rapid action on climate change to limit warming in line with Paris Agreement goals. Their activists behave environmentally friendly, at some personal sacrifice, and demand the same of their peers and parents, using their status as future-affected to derive a position as a moral and ethical vanguard. In contrast to other findings (Zabern \& Tulloch, 2021), my results show that these positions are portrayed across the media analysed.

The Sunrise Movement could be seen as a US counterpart, but it has been readily subsumed under the liberal/Democrat political identity label. Arguably, we're living in an era of "identity politics," where most political contestation is organised around "struggles for recognition" of one's situation (Honneth, 2012). Having an independent, somewhat non-partisan recognised identity means being able to influence public and political discourse while allowing all parties to respond in a way that tries to co-opt part of the movement via attempts to have a stronger profile on the climate as part of their identity.

In sum, I argue that the media portrayals of the political and party identities analysed here should be read as evidence of an ongoing transformation of political identities in response to climate change becoming an increasingly important political issue. Yet, my findings also reveal how portrayals of parties differ at times remarkably between outlets consumed by left- and right-leaning audiences. These differences offer an important piece of evidence linking media portrayals to changing attitudes towards climate politics and policies.

\section{Polarisation and oppositional identity portrayals}

The first striking observation is that the 'polar media', read more exclusively by left- or rightleaning audiences, tend to emphasise differences between parties, particularly in the US. This tendency, not unique to the case of climate change, is likely to reinforce polarisation and "perception gaps" (Yudkin et al., 2019) between partisans. In both countries, polar media 
outlets tend to portray audience-outgroup identities in a way that is likely to create opposition to that identity among their typical audience.

This tendency is most apparent in the US, where Fox News portrays Democrats as fear-mongering socialists using climate change as a pretence for a government take-over, with Republican positions reduced to opposition to these efforts. And indeed, opinion change among Republicans (in particular Fox News recipients) is a key factor in developing partisan polarisation over the Green New Deal (Gustafson et al., 2019). Conversely, Huffington Post paints all Republicans as climate deniers, contributing their share to the widening gap.

In the German case, similar tendencies are at play, but they are less pronounced. Bild emphasises that the Greens (and the SPD) want to work with strict prohibitions, whereas this information is less central in the other two outlets. On the other end, SZ portrays the Union parties as out of touch, and the Greens to be the only party with a sense for the "Zeitgeist". Yet, across all outlets, the parties discussed here share a consensus regarding the necessity to considerably reduce emissions over the coming decade.

In addition to emphasising negative traits of political identities likely opposed by the audience, polar outlets tend to portray both left- and right-wing identities as more prototypical - with less diversity and in-group disagreement - than the 'centrist' media. This is remarkable, as intra-party conflict arguably holds news value (Bennett, 1996) and is covered in centrist media. The tendency to emphasise prototypicality appears to be most pronounced in Fox News, where no portrayals of disagreement among Republicans or Democrats were found in the sample. German polar outlets reported on divisions within the left- and rightwing blocks, but portrayals of within-party divisions are equally rare. In line with the first tendency, prototypicality is likely to enhance the effects of group portrayals (Seyranian, 2014).

I suggest that the combination of both tendencies (negative outgroup portrayals and high prototypicality) results in an identity-affirming reporting style avoiding confrontation with cues creating dissonance with existing perceptions of partisan identities. In the US, these portrayals reinforce perceptions of identity prototypes that contain beliefs about climate change and policy positions deeply enmeshed with fundamental beliefs associated with either party, emphasising existing divides concerning values (Lucas, 2018) and attitudes towards policy (Pechar et al., 2018). This dynamic is, in my view, likely one of the reasons why selective exposure tends to reinforce existing worldviews in the US (Newman et al., 2018b).

In the German case, similar reporting patterns are at play - however, fundamentally speaking, climate change appears as a unifying force, with most party identities including a pro-climate stance. Divisions over policy thus seem much less fundamental, and the within- 
block divisions lead to stances on the issue mapping less neatly on the left-right scale. German media thus facilitate consensus-building across political identities, whereas US media tend to reinforce polarisation that possibly already exists at the identity level (Bliuc et al., 2015).

The drivers of these country-level differences lie, in my view, in the political and media landscape. Politically speaking, the German multi-party system creates multiple lines of divisions that do not map as neatly on a left-right scale as the US two-party system does, and the media systems in both countries exacerbate political tendencies. In the US, large shares of news recipients consume what I described as 'polar media', while the centrist media are relatively unpopular (figure 1 in the Methods section). In Germany, on the other hand, more centrist outlets are consumed widely, whereas the polar media cater to smaller audiences. In addition, a large state-funded but politically independent, free public broadcasting system (Brüggemann et al., 2014) offering an ostensibly "neutral" perspective creates pressure on the polar media to appeal to politically diverse audiences to increase market shares. Taken together, my findings and these observations suggest that the different media systems of these two countries do their fair share in exaggerating existing identity polarisation (in the United States) and building centrist consent across party lines and political identities (Germany).

\section{Limitations}

These generalisations should be read as the outcome of an inductive theorising process underlying a range of limitations. First and foremost, the propositions I put forward have not undergone quantified theory-testing. While I consistently cross-checked my findings and accounts with the available data, further research is needed that quantitatively operationalises the concepts I use, such as audience-adjusted identity portrayals and identity prototypicality. Such an operationalisation could be used for quantitative theory-testing of the proposition that 'polar media' tend to emphasise prototypicality and negative outgroup-portrayals. Quantification also can enable testing these hypotheses in the context of other politically contentious issues or in other countries.

Second, my findings are based on data gathered in a period marked by some idiosyncratic events. In the United States, the onset of the Democratic primary campaigns meant that candidates had to present policy ideas and priorities to sharpen their profiles, which is likely to generate more extreme positions. In Germany, the Fridays for Future movement and the European election heightened attention for the issue, which pushed political actors to adopt positions that otherwise could have avoided the issue altogether. While the observed 
tendencies and cross-country differences might be less pronounced in other circumstances, I do not believe that they critically influence the direction of my findings. Yet, a longitudinal perspective would be very valuable.

Third, from a theoretical perspective, I want to stress that the present analysis is focused on portrayals of political identities rather than the perceptions of news recipients. I have discussed some reasons to believe that mediatised portrayals might impact individually held beliefs about in- and outgroup political identities. Yet further empirical research is needed to test the role of identity perceptions as a mechanism to explain polarisation over politically contentious issues, such as climate change.

\section{Concluding Remarks}

To conclude, based on the systematic qualitative analysis I conducted, I would argue that, indeed, climate change is increasingly becoming a considerable element of existing partisan political identities. It also shapes a new political identity based on the young's status as strongly affected by climatic changes. In addition, my findings suggest that 'polar media' consumed by primarily right or left-leaning audiences can contribute to identity polarisation. They vary in their portrayals of the identities in a way that often reinforces their audiences' existing perceptions of political groups' beliefs and attitudes towards climate change.

Overall, my findings indicate that the more exclusively an outlet is read by the political left or right, the narrower its portrayals of political identities and the role of knowledge about climate change and policy within them. In the light of these findings, one of the key challenges for political movements aiming to push for a more significant response to climate change lies in finding ways to have their ideas become a positively integrated part of partisan identities across the political spectrum or develop one that can develop political force on its own. To do so, they must navigate a media landscape where some outlets tend to exaggerate and polarise, posing a considerable communicative challenge.

\section{References}

Båtstrand, S. (2015). More than Markets: A Comparative Study of Nine Conservative Parties on Climate Change. Politics \& Policy, 43(4), 538-561. https://doi.org/10.1111/polp.12122

Bennett, W. L. (1996). An introduction to journalism norms and representations of politics. Political Communication, 13(4), 373 384. https://doi.org/10.1080/10584609.1996.9963126 
Benwell, B., \& Stokoe, E. (2006). Discourse and identity. Edinburgh University Press.

Bliuc, A.-M., McGarty, C., Thomas, E. F., Lala, G., Berndsen, M., \& Misajon, R. (2015).

Public division about climate change rooted in conflicting socio-political identities. Nature Climate Change, 5(3), 226-229. https://doi.org/10.1038/nclimate2507

Bolsen, T., \& Shapiro, M. A. (2017). The US News Media, Polarisation on Climate Change, and Pathways to Effective Communication. Environmental Communication, 12(2), 149-163. https://doi.org/10.1080/17524032.2017.1397039

Boykoff, M. T. (2008). The cultural politics of climate change discourse in UK tabloids. Political Geography, 27(5), 549-569. https://doi.org/10.1016/j.polgeo.2008.05.002

Brown, R. (2020). The social identity approach: Appraising the Tajfellian legacy. British Fournal of Social Psychology, 59(1), 5-25. https://doi.org/10.1111/bjso.12349

Brüggemann, M., Engesser, S., Büchel, F., Humprecht, E., \& Castro, L. (2014). Hallin and Mancini Revisited: Four Empirical Types of Western Media Systems. Fournal of Communication, 64(6), 1037-1065. https://doi.org/10.1111/jcom.12127

Carvalho, A., Wessel, M. van, \& Maeseele, P. (2017). Communication Practices and Political Engagement with Climate Change: A Research Agenda. Environmental Communication, 11(1), 122-135. https://doi.org/10.1080/17524032.2016.1241815

Chong, D., \& Druckman, J. N. (2007). Framing Theory. Annual Review of Political Science, 10(1), 103-126. https://doi.org/10.1146/annurev.polisci.10.072805.103054

Clark, A., Justwan, F., Carlisle, J. E., \& Clark, M. (2019). Polarisation politics and hopes for a green agenda in the United States. Environmental Politics, 29(4), 719-745. https://doi.org/10.1080/09644016.2019.1654238

Ellemers, N., Spears, R., \& Doosje, B. (2002). Self and Social Identity. Annual Review of Psychology, 53(1), 161-186. https://doi.org/10.1146/annurev.psych.53.100901.135228

Farstad, F. M. (2017). What explains variation in parties' climate change salience? Party Politics, 24(6), 698-707. https://doi.org/10.1177/1354068817693473

Feldman, L., Maibach, E. W., Roser-Renouf, C., \& Leiserowitz, A. (2011). Climate on Cable. The International fournal of Press/Politics, 17(1), 3-31. https://doi.org/10.1177/1940161211425410

Feldman, L., Myers, T. A., Hmielowski, J. D., \& Leiserowitz, A. (2014). The Mutual Reinforcement of Media Selectivity and Effects: Testing the Reinforcing Spirals Framework in the Context of Global Warming. Fournal of Communication, 64(4), 590-611.

https://doi.org/10.1111/jcom. 12108 
Ford, R., \& Jennings, W. (2020). The Changing Cleavage Politics of Western Europe. Annual Review of Political Science, 23(1), 295-314. https://doi.org/10.1146/annurev-polisci052217-104957

Glaser, B. G., \& Holton, J. (2004). Remodeling Grounded Theory. Forum Qualitative Sozialforschung / Forum: Qualitative Social Research, 5(2).

Grant, Z. P., \& Tilley, J. (2018). Fertile soil: explaining variation in the success of Green parties. West European Politics, 42(3), 1-22. https://doi.org/10.1080/01402382.2018.1521673

Gustafson, A., Rosenthal, S. A., Ballew, M. T., Goldberg, M. H., Bergquist, P., Kotcher, J. E., Maibach, E. W., \& Leiserowitz, A. (2019). The development of partisan polarisation over the Green New Deal. Nature Climate Change, 9(12), 940-944.

https://doi.org/10.1038/s41558-019-0621-7

Hallin, D. G., \& Mancini, P. (2004). Comparing Media Systems. Cambridge: Cambridge University Press.

Hart, P. S., \& Nisbet, E. C. (2012). Boomerang Effects in Science Communication. Communication Research, 39(6), 701 -723. https://doi.org/10.1177/0093650211416646

Hogg, M. A., \& Reid, S. A. (2006). Social Identity, Self-Categorization, and the Communication of Group Norms. Communication Theory, 16(1), 7-30. https://doi.org/10.1111/j.14682885.2006.00003.x

Honneth, A. (2012). Brutalisation of the social conflict: struggles for recognition in the early 21 st century. Distinktion: Scandinavian Fournal of Social Theory, 13(1), 5-19. https://doi.org/10.1080/1600910x.2012.648736

Huddy, L. (2015). Group Identity and Political Cohesion. In Emerging Trends in the Social and Behavioral Sciences. https://doi.org/10.1002/9781118900772.etrds0155

Latour, B. (2005). Reassembling the Social. Oxford: Oxford University Press.

Light, A. (2000). What is an ecological identity? Environmental Politics, 9(4), 59-81. https://doi.org/10.1080/09644010008414551

Lucas, C. H. (2018). Concerning values: what underlies public polarisation about climate change? Geographical Research, 17(2). https://doi.org/10.1111/1745-5871.12284

Michael, M. (2017). Actor Network Theory. Sage Publishing.

Morris, H. E. (2020). Constructing the Millennial "Other" in United States Press Coverage of the Green New Deal. Environmental Communication, 15(1), 133-143. https://doi.org/10.1080/17524032.2020.1812686 
Newman, N., Fletcher, R., Kalogeropoulos, A., Levy, D. A. L., \& Nielsen, R. K. (2018a). Reuters Institute Digital News Report 2018. Reuters Insitute for the Study of Journalism. https://reutersinstitute.politics.ox.ac.uk/sites/default/files/digital-news-report-2018.pdf

Newman, T. P., Nisbet, E. C., \& Nisbet, M. C. (2018b). Climate change, cultural cognition, and media effects: Worldviews drive news selectivity, biased processing, and polarised attitudes: Public Understanding of Science, 27(8), 985-1002. https://doi.org/10.1177/0963662518801170

Pechar, E., Bernauer, T., \& Mayer, F. (2018). Beyond Political Ideology: The Impact of Attitudes Towards Government and Corporations on Trust in Science. Science Communication, 24(1), 107554701876397 23. https://doi.org/10.1177/1075547018763970

Pepermans, Y., \& Maeseele, P. (2018). Manufacturing Consent: Rereading News on Four Climate Summits (2000-2012). Science Communication, 40(5), 621-649. https://doi.org/10.1177/1075547018798119

Reese, S. D., \& Shoemaker, P. J. (2016). A Media Sociology for the Networked Public Sphere: The Hierarchy of Influences Model. Mass Communication and Society, 19(4), 389410. https://doi.org/10.1080/15205436.2016.1174268

Rugeley, C. R., \& Gerlach, J. D. (2012). Understanding Environmental Public Opinion by Dimension: How Heuristic Processing Mitigates High Information Costs on Complex Issues. Politics \& Policy, 40(3), 444-470. https://doi.org/10.1111/j.1747-1346.2012.00352.x

Schmid-Petri, H. (2015). Do Conservative Media Provide a Forum for Skeptical Voices? The Link Between Ideology and the Coverage of Climate Change in British, German, and Swiss Newspapers. Environmental Communication, 11(4), 554-567. https://doi.org/10.1080/17524032.2017.1280518

Schmid-Petri, H. (2017). Politicisation of science: how climate change skeptics use experts and scientific evidence in their online communication. Climatic Change, 145(3-4), 523537. https://doi.org/10.1007/s10584-017-2112-z

Seyranian, V. (2014). Social identity framing communication strategies for mobilising social change. The Leadership Quarterly, 25(3), 468-486. https://doi.org/10.1016/j.leaqua.2013.10.013

Tavory, I., \& Timmermans, S. (2014). Abductive Analysis. University of Chicago Press, 176.

The Republican Party (2016). The 2016 Republican Party Platform. https://www.presidency.ucsb.edu/documents/2016-republican-party-platform. Accessed May 5, 2021. 
Tschötschel, R., Schuck, A., \& Wonneberger, A. (2020). Patterns of controversy and consensus in German, Ganadian, and US online news on climate change. Global Environmental Change, 60, 101957. https://doi.org/10.1016/j.gloenvcha.2019.101957

Turner, J. C., Oakes, P. J., Haslam, S. A., \& McGarty, C. (1994). Self and Collective: Cognition and Social Context. Personality and Social Psychology Bulletin, 20(5), 454-463. https://doi.org/10.1177/0146167294205002

Venturini, T. (2009). Diving in magma: how to explore controversies with actor-network theory. Public Understanding of Science, 19(3), 258-273.

https://doi.org/10.1177/0963662509102694

Vos, T., \& Shoemaker, P. J. (2009). Gatekeeping Theory. New York: Routledge. https://doi.org/10.4324/9780203931653

Weingart, P., Engels, A., \& Pansegrau, P. (2000). Risks of communication: discourses on climate change in science, politics, and the mass media. Public Understanding of Science, 9(3), 261-283. https://doi.org/10.1088/0963-6625/9/3/304

Werff, E. van der, Steg, L., \& Keizer, K. (2013). The value of environmental self-identity: The relationship between biospheric values, environmental self-identity and environmental preferences, intentions and behaviour. Fournal of Environmental Psychology, 34, 55-63. https://doi.org/10.1016/j.jenvp.2012.12.006

Yudkin, D., Hawkins, S., \& Dixon, T. (2019). The perception gap: how false impressions are pulling Amercians apart [Report]. More in Common. https://perceptiongap.us/media/zaslaroc/perception-gap-report-1-0-3.pdf

Zabern, L. von, \& Tulloch, C. D. (2021). Rebel with a cause: the framing of climate change and intergenerational justice in the German press treatment of the Fridays for Future protests. Media, Culture E̊ Society, 43(1), 23-47. https://doi.org/10.1177/0163443720960923 